\title{
Shell decay rates of native and alien freshwater bivalves and implications for habitat engineering
}

\author{
DAVID L. STRAYER AND HEATHER M. MALCOM \\ Institute of Ecosystem Studies, Millbrook, NY U.S.A.
}

\begin{abstract}
SUMMARY
1. Spent shells of bivalves can provide habitat for other organisms, as well as playing important roles in biogeochemical cycles. The amount of spent shell material that will accumulate at a site depends on rates of both shell production and decay, although the latter is rarely considered.

2. We measured the instantaneous decay rates of four species of freshwater bivalves across a range of sites in south-eastern New York, and found that rates varied by more than 500 -fold across sites and species.

3. Differences in decay rates were related to water chemistry $(\mathrm{Ca}, \mathrm{pH}$, dissolved inorganic C), the presence of a current, and the size of the bivalve shell.

4. Combining these decay rates with estimates of shell production derived from the literature, we conclude that the Unionidae, Corbicula, and Dreissena are all capable of producing large accumulations ( $>10 \mathrm{~kg}$ dry mass $\mathrm{m}^{-2}$ ) of spent shells, while members of the Sphaeriidae probably rarely will produce such large accumulations.

5. Hence the replacement of native unionid bivalves by the alien Corbicula and Dreissena may have little effect on standing stocks of spent shells, unless the aliens invade sites where unionids are scarce or absent.
\end{abstract}

Keywords: aragonite, calcite, calcium carbonate, dissolution, ecological engineering

\section{Introduction}

Bivalves can be important in aquatic ecosystems because they graze phytoplankton and regenerate nutrients (e.g. Dame, 1996; Strayer et al., 1999; Vaughn \& Hakenkamp, 2001), but also because they act as ecological engineers by creating large amounts of shell (Gutierrez et al., 2003). This shell material can persist for a long time after the bivalve dies, providing habitat for other organisms, especially in soft sediments (Gutierrez et al., 2003), and playing an important part in cycling of $\mathrm{CO}_{2}$ and $\mathrm{Ca}$ (e.g. Green, 1980; Chauvaud et al., 2003; Barbiero, Tuchman \& Millard, 2006). Discussions of the importance of bivalve shells typically focus solely on rates of shell

Correspondence: David L. Strayer, Institute of Ecosystem

Studies, PO Box AB, Millbrook, NY 12545, U.S.A.

E-mail: strayerd@ecostudies.org production (e.g. Chauvaud et al., 2003), but the amount of shell material that is accumulated by a bivalve population also depends on rates of shell decay. Shell decay has been studied by marine geochemists and ecologists (e.g. Glover \& Kidwell, 1993; Harper, 2000; Powell, Kraeuter \& AshtonAlcox, 2006), but rarely considered by freshwater ecologists. Nevertheless, concentrations of calcium carbonate vary much more widely in fresh waters than in the ocean, so shell decay rates likewise should be highly variable in fresh waters, and play a critical role in determining the extent of habitat engineering by freshwater bivalves.

Specifically, the dynamics of the spent shell pool are described by

$$
\frac{\mathrm{d} S}{\mathrm{~d} t}=M-l S
$$

where $S$ is the standing stock of spent shells, $M$ is the quantity of shell material entering the spent shell pool 
through mortality of living animals and $l$ is the instantaneous loss rate of spent shells. At steady state, mortality is equal to the production of spent shells $(P)$ and $\mathrm{d} S / \mathrm{d} t=0$, so the quantity of spent shell material will be $P / l$. Rates of shell loss should depend on water chemistry and current speed, and should also vary substantially across bivalve species that differ in shell size and composition.

Highly variable rates of shell production and loss across freshwater environments and bivalve species will lead to wide variation in the importance of habitat engineering by freshwater bivalves. In particular, the widespread replacement of native bivalves with aliens such as Dreissena spp. and Corbicula spp. at many sites around the world (e.g. Karatayev, Burlakova \& Padilla, 2005) raises the possibility that important changes in habitat engineering may accompany these species replacements. Nevertheless, the very few measurements that have been made of either shell production (Aldridge \& McMahon, 1978; Strayer et al., 1981; Vincent, Vaillancourt \& Lafontaine, 1981; Vincent \& Lafontaine, 1984) or decay (Strayer et al., 1981) by freshwater bivalves are insufficient to evaluate the importance of habitat engineering by freshwater bivalves across environments or species.

The goals of our study were to measure rates of shell loss of the four major groups of freshwater bivalves (Unionidae, Corbiculidae, Sphaeriidae, Dreissenidae) across a range of environments differing in water chemistry and current speed. We combine this information with available data on shell production to identify the environments and species for which habitat engineering is most important, and assess whether replacement of natives by aliens is likely to be important in changing habitat engineering.

\section{Methods}

Our basic approach was to deploy 'litter bags' containing shells of different species of bivalves across a range of sites differing in water movement and chemistry. We chose the study sites to represent a wide range of chemical and physical conditions in a small geographic area (Table 1). The four bivalve species chosen (Table 2) are common representatives of the four families of bivalves that are now widespread in fresh waters across the Northern Hemisphere. The shells of all of these families are composed of aragonite rather than calcite; only the shells of unionids contain internal layers of conchiolin (Compere \& Bates, 1973; Kat, 1985; Fritz et al., 1990; Pathy \& Mackie, 1993). We used both fresh spent shells (Corbicula fluminea, Elliptio complanata, and Sphaerium striatinum) and shells from living animals (Dreissena polymorpha and Sphaerium striatinum). Spent shells were rinsed to remove dirt and debris, then airdried; living animals were killed by freezing, then the bodies were removed from the shells and the shells were air-dried.

We made litter bags out of 1.6-mm mesh fibreglass window screening. Each bag contained several preweighed valves of a single bivalve species plus a numbered aluminum tag, and was sealed with a soldering iron. We cabled each bag onto a $30-\mathrm{cm}$ steel spike, which we drove into the sediments in the shallow water (approximately $0.5 \mathrm{~m}$ deep at low water) at each study site (Table 1). Bags were widely dispersed ( $>1 \mathrm{~m}$ apart) over the study site and rested flat on the sediment surface. We placed bags into the field on 7-8 October 2004 and retrieved them on 13-14 September 2005. A large flood moved a few of the bags from the Neversink River and Spring Brook onto the floodplain on 3 April 2005; we collected these bags

Table 1 Characteristics of the study sites, including means and ranges (in parentheses) of water-chemistry variables over the four collection times. Running-water sites had sand and gravel bottoms; standing-water sites had mud bottoms

\begin{tabular}{llll}
\hline Site & $\mathrm{pH}$ & $\mathrm{DIC}\left(\mathrm{mg} \mathrm{L}^{-1}\right)$ & $\mathrm{Ca}\left(\mathrm{mg} \mathrm{L}^{-1}\right)$ \\
\hline Duck Pond, Ulster Co., New York & $7.36(7.1-7.6)$ & $10.7(8.3-12.3)$ & $10.2(7.7-11.7)$ \\
East Branch Wappinger Creek, Dutchess Co., New York & $7.99(7.6-8.4)$ & $25.9(17.6-30.8)$ & $29.6(23.3-38.4)$ \\
Fowler Road Pond, Dutchess Co., New York & $7.23(6.5-7.6)$ & $5.58(4.3-7.3)$ & $5.66(4.1-8.5)$ \\
Neversink River, Orange Co., New York & $7.28(6.8-7.8)$ & $3.95(3.2-5.0)$ & $7.13(6.5-7.8)$ \\
Spring Brook, Orange Co., New York & $6.63(6.2-6.9)$ & $7.26(6.2-8.6)$ & $9.95(9.4-10.5)$ \\
Spring Lake, Dutchess Co., New York & $8.03(7.5-8.4)$ & $28.8(25.4-31.1)$ & $39.6(29.5-45.7)$ \\
\hline
\end{tabular}




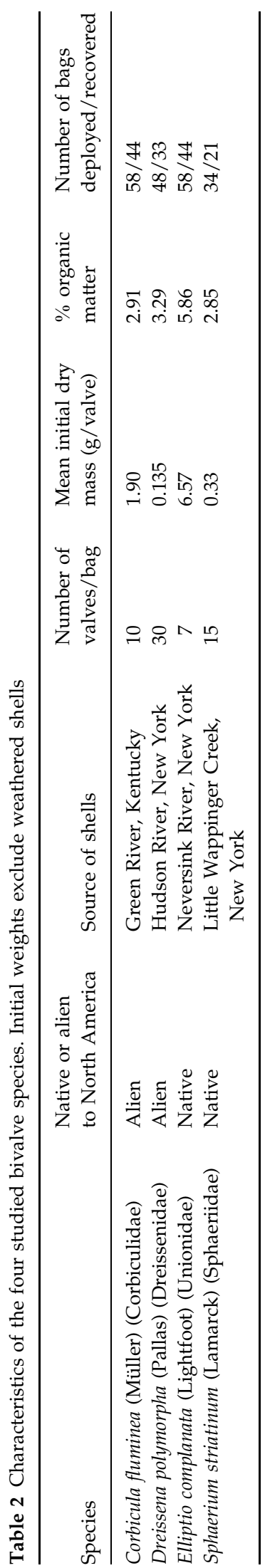

on 2 June 2005. In total, we recovered 142 of the 198 bags initially deployed (Table 2).

At each site, we placed eight bags of each species except for Sphaerium, for which insufficient material forced us to deploy just four bags/site. We also prepared a few additional litter bags containing somewhat weathered shells; our analyses showed no statistical differences in decay rates between fresh and weathered shells, so we included these additional bags in all of our analyses.

After bags were retrieved from the field, shells were removed, lightly rinsed to remove debris, air-dried, weighed, ashed at $450{ }^{\circ} \mathrm{C}$ for $8 \mathrm{~h}$ and then reweighed. We assume that the ash-free dry mass represents $\mathrm{CaCO}_{3}$, and the mass lost on ashing represents organic matter. At least 10 bags of shells of each species identical to those deployed in the field were kept back for measurement of initial organic and $\mathrm{CaCO}_{3}$ content.

We measured water chemistry at each site four times over the course of the study (October 2004, and January, June and September 2005). We measured $\mathrm{pH}$ in the field with an Accumet AP60 Series pH meter (Fisher Scientific, Pittsburgh, PA, U.S.A.). We took samples for dissolved inorganic C (DIC) in 300-mL glass BOD bottles and refrigerated the samples until measuring DIC on a Shimadzu 8A gas chromatograph (Shimadzu Scientific Instruments, Columbia, MD, U.S.A.) with thermal conductivity detector (Stainton, 1974). Ca was measured with a Leeman Labs Inductively Coupled Plasma Spectrometer (Teledyne Technologies, Los Angeles, CA, U.S.A.) on samples taken in clean polyethylene bottles. The sites ranged from highly undersaturated with $\mathrm{CaCO}_{3}$ to two sites (Spring Lake and the East Branch of Wappinger Creek) that fluctuated between supersaturation and undersaturation on different sampling dates, according to the equations in Butler (1991). Water movement was assessed as a binary variable (i.e. running water versus standing water).

We calculated the instantaneous rate of shell loss $\left(k\right.$, year $\left.^{-1}\right)$ as

$$
k=(1 / t)\left[\ln \left(\frac{\text { mass }_{\text {final }}}{\text { mass }_{\text {initial }}}\right)\right]
$$

where $t$ is the length of time (in years) that the shells were in the water. We calculated $k$ separately for the bulk shell material, the organic fraction of the shell and the $\mathrm{CaCO}_{3}$ fraction of the shell. 
1614 D. L. Strayer and H. M. Malcom

Three of the litter bags contained no shell material when they were recovered, making it impossible for us to estimate $k$. Simply discarding data from these bags would have biased our estimates of decay rates, so we estimated $k$ by assuming that the amount of shell material remaining in these bags was half of the minimum remaining mass we observed for that species at that site. We discarded data from one bag of Elliptio from the East Branch of Wappinger Creek as an outlier because $k$ for this bag was -0.50 , whereas other bags from this site had $k=-0.03$ to -0.06 .

\section{Results}

Instantaneous decay rates of bulk shell material varied enormously, ranging from -0.01 to $<-5$ year $^{-1}$ and corresponding to annual losses of $1.1 \%$ to $>99 \%$. Decay rates were significantly related to both bivalve species (two-way ANOVA, $F=17.2, P<0.0001$ ) and site $(F=12.9, P<0.0001)$. Differences in decay rates among sites were correlated with both water movement and chemistry, and were much faster at sites where the water was both moving and soft than at sites where the water was still or hard (whether expressed as $\mathrm{Ca}, \mathrm{DIC}$, or $\mathrm{pH}$ ) (Fig. 1). Differences in decay rates across species were related to the size of the shell; small shells decayed much more quickly than large shells (Fig. 2). Loss rates of the inorganic and organic fractions of the shell were similar (Fig. 3),

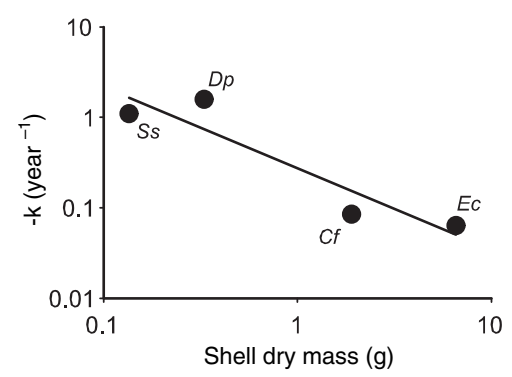

Fig. 2 Decay rates of four different species of freshwater bivalves, averaged over all study sites except the Neversink River (at which no Sphaerium bags survived), as a function of mean shell mass of each species $\left(r^{2}=0.86, P<0.04\right)$. Full species names are given in Table 2.

although as expected decay rates of organic matter relative to those of $\mathrm{CaCO}_{3}$ were a little higher in hard waters than in soft waters.

\section{Discussion}

The very wide range in shell decay rates that we observed can be explained by water chemistry, water movement and the size of the bivalve shell. If the full range of bivalve species [adult shell mass ranging from $<1 \mathrm{mg}$ to $>1 \mathrm{~kg}$ DM (dry mass)/individual] and environmental conditions in fresh waters is considered (very soft to supersaturated with $\mathrm{CaCO}_{3}$ ), then rates of shell decay will vary even more than the 500fold observed in our study. Ultimately it may be

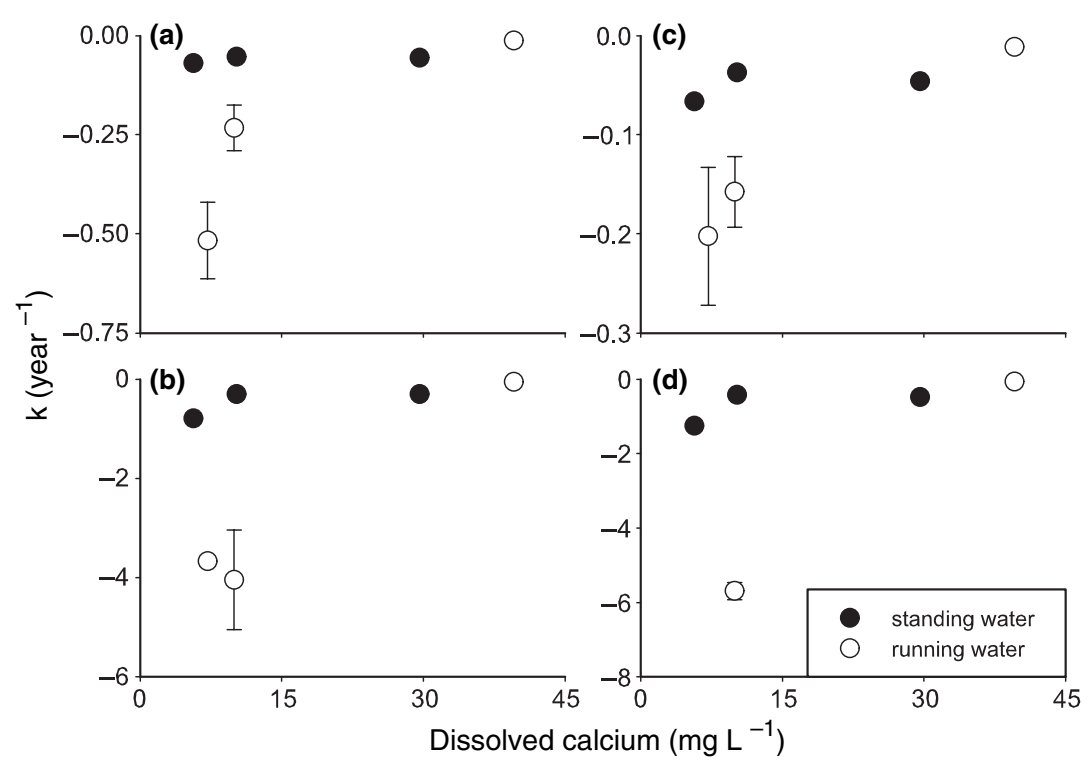

Fig. 1 Mean decay rates $( \pm 1 \mathrm{SE})$ of four species of freshwater bivalves across a range of sites in south-eastern New York, as a function of dissolved $\mathrm{Ca}$ in the water. Species are (a) Corbicula fluminea, (b) Dreissena polymorpha, (c) Elliptio complanata and (d) Sphaerium striatinum. Note the large differences in scales on the $Y$-axes. 


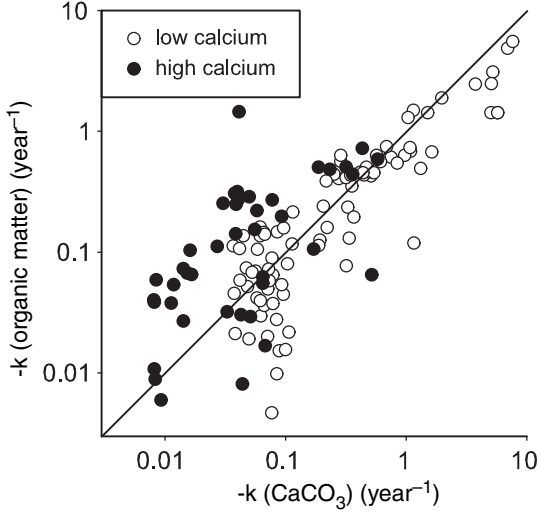

Fig. 3 Comparison of decay rates for $\mathrm{CaCO}_{3}$ and organic matter for individual litter bags in sites with low $\mathrm{Ca}\left(<11 \mathrm{mg} \mathrm{L}^{-1}\right)$ or high $\mathrm{Ca}\left(>29 \mathrm{mg} \mathrm{L}^{-1}\right)$. The regression of organic matter decay rates on $\mathrm{CaCO}_{3}$ decay rates and environmental $\mathrm{Ca}$ is highly significant $\left(r^{2}=0.68, P<0.0001\right)$. The diagonal line is the $1: 1$ line of equal decay rates for $\mathrm{CaCO}_{3}$ and organic matter.

possible to produce a satisfactory general model of shell decay in fresh waters using shell size, water chemistry, current, and temperature as independent variables. The close relationships between decay rates for shell organic matter and $\mathrm{CaCO}_{3}$, and between decay rates and $\mathrm{CaCO}_{3}$ content of the water, suggest that the decomposition rate of shell organic matter may be controlled by the rate of $\mathrm{CaCO}_{3}$ dissolution, at least in the predominately undersaturated waters that we studied.

In general terms, shell decay rates are controlled by both extrinsic factors (water chemistry and movement, mechanical abrasion) and intrinsic factors (shell size, $\mathrm{CaCO}_{3}$ crystal size and mineralogy, chemical composition and structure of organic matter). In waters that are near $\mathrm{CaCO}_{3}$ saturation, decay rates may be controlled chiefly by microbial decomposition of organic matter, which makes $\mathrm{CaCO}_{3}$ crystals available to physical abrasion or chemical dissolution (Glover \& Kidwell, 1993). In contrast, chemical dissolution (which presumably also enhances physical abrasion of particles of $\mathrm{CaCO}_{3}$ and organic matter) may be the rate-limiting step for shell decay in highly undersaturated waters.

Rates of shell production by freshwater bivalves rarely have been measured, and so generally have to be estimated indirectly. For unionids, the standing stock of living shells in the dense population of unionids living in the upper Hudson River before the zebra mussel invasion was $731 \mathrm{~g} \mathrm{DM} \mathrm{m}^{-2}$ (D.L.
Strayer, unpublished data, based on methods described by Strayer et al., 1994). If the annual production/biomass ratio was approximately 0.2 (Strayer et al., 1981; Nalepa \& Gauvin, 1988), then annual production of shells by this community would have been approximately $150 \mathrm{~g} \mathrm{DM} \mathrm{m}^{-2}$ year $^{-1}$. Shell production in the densest unionid communities thus might reach approximately $1 \mathrm{~kg} \mathrm{DM} \mathrm{m}^{-2}$ year $^{-1}$, but probably more typically is $0.1-10 \mathrm{~g} \mathrm{DM} \mathrm{m}^{-2}$ year $^{-1}$. The production of organic matter in shells of Dreissena polymorpha ranges from 0.7 to $53 \mathrm{~g} \mathrm{C} \mathrm{m}^{-2}$ year $^{-1}$ (Cleven \& Frenzel, 1993; Chase \& Bailey, 1999). If we assume that organic $C$ constitutes $0.53 \%$ of shell mass (Walz, 1979), then corresponding rates of shell production rates would be $130-10000 \mathrm{~g}$ $\mathrm{DM} \mathrm{m}^{-2}$ year $^{-1}$. Perhaps rates of $10-10000 \mathrm{~g}$ $\mathrm{DM} \mathrm{m}^{-2}$ year $^{-1}$ are typical of Dreissena populations. Estimates of production of body tissue by Corbicula range from 0.6 to $14.6 \mathrm{~g} \mathrm{DM} \mathrm{m}^{-2}$ year $^{-1}$ (Chase \& Bailey, 1999). Aldridge \& McMahon (1978) found that shell production was approximately 30 times organic production, suggesting that the populations of Corbicula that have been studied had shell production rates of $18-400 \mathrm{~g} \mathrm{DM} \mathrm{m}^{-2}$ year $^{-1}$. Dense populations of Corbicula might therefore produce more than $1 \mathrm{~kg} \mathrm{DM} \mathrm{m}^{-2}$ year $^{-1}$ of shell. Two fairly dense populations of sphaeriids in the St Lawrence River produced only $1.2-13.3 \mathrm{~g} \mathrm{DM} \mathrm{m}^{-2}$ year $^{-1}$ of shell (Vincent et al., 1981; Vincent \& Lafontaine, 1984). From these estimates, it seems doubtful that even dense populations of sphaeriids produce $>100 \mathrm{~g} \mathrm{DM} \mathrm{m}^{-2}$ year $^{-1}$ of shell. Combining these estimates of shell production with our estimates of shell decay, we see that unionids, Dreissena, and Corbicula are all capable of producing large amounts $\left(>10 \mathrm{~kg} \mathrm{DM} \mathrm{m}^{-2}\right.$ ) of spent shells in standing or hard waters, while sphaeriids probably rarely produce large pools of spent shells (Fig. 4).

The estimates of shell accumulation in Fig. 4 are only rough calculations. In addition to violations of the assumption of steady state, processes such as burial, fluvial transport, physical abrasion, and feedbacks between spent shells and recruitment of young bivalves (e.g. Chase \& Bailey, 1996) may cause deviations from the predictions of Fig. 4 over the long term. Nevertheless, Fig. 4 clearly delimits circumstances in which habitat engineering by bivalves is likely to be important or unimportant. If the water is soft and moving, it is unlikely that spent shells of even 


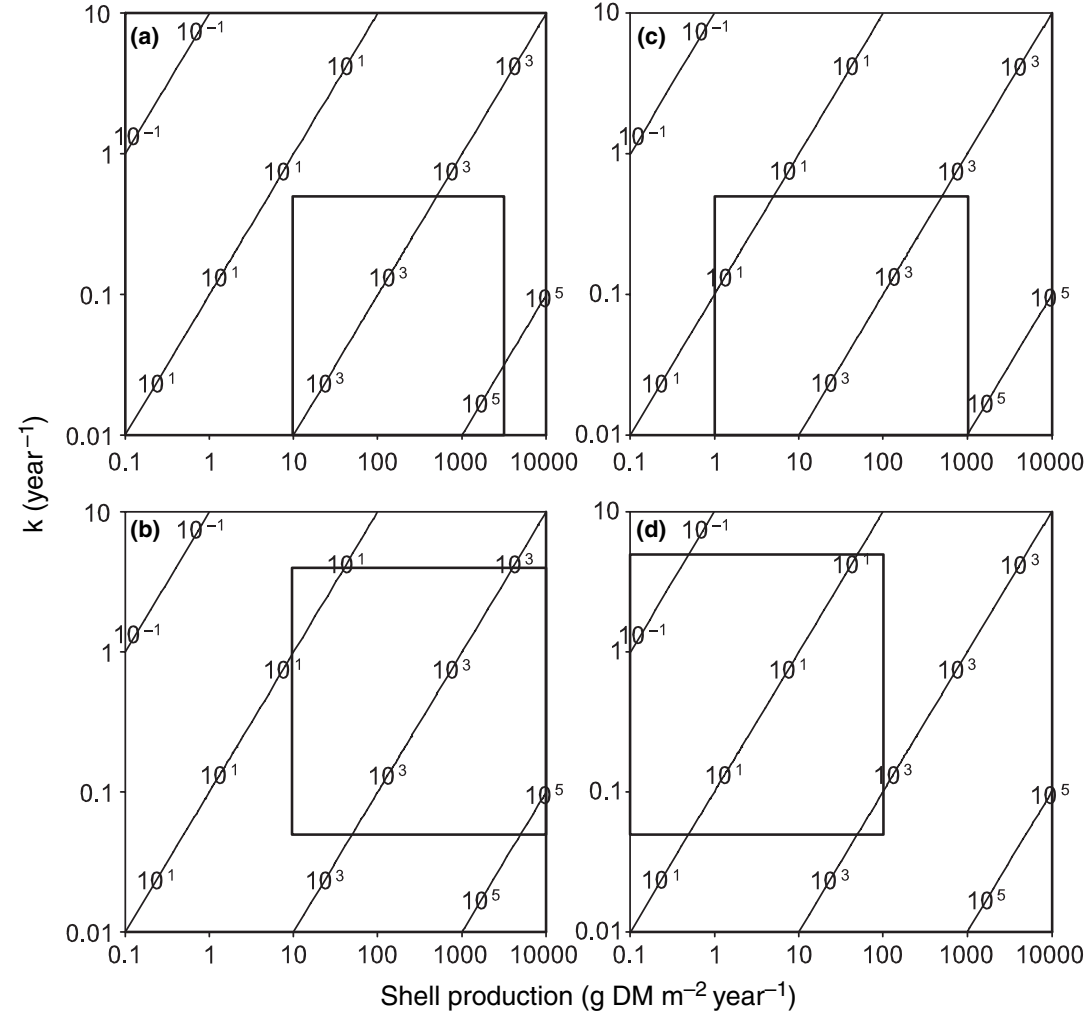

Fig. 4 Estimated steady-state standing stocks of spent shells (contour lines, in $\mathrm{g} \mathrm{DM} \mathrm{m}^{-2}$ year $^{-1}$ ) for four species of bivalves as a function of rates of shell production and decay: (a) Corbicula fluminea; (b) Dreissena polymorpha; (c) Elliptio complanata; (d) Sphaerium striatinum. Heavy rectangles delimit the range of production and decay rates most likely to occur in nature for each bivalve (see text for explanation). dense populations of bivalves will be important in habitat creation or sequestration of calcium carbonate. In contrast, in hard water or in lakes, even modest populations of bivalves may accumulate large amounts of spent shells, and the combination of hard water, high shell production, and large shells (such as may have prevailed in Midwestern rivers in preColumbian times) may lead to very substantial (10$100 \mathrm{~kg} \mathrm{~m}^{-2}$ ) shell accumulation, with important consequences for habitat structure and biogeochemical cycling.

Surprisingly, Fig. 4 suggests that the replacement of native unionids by Corbicula or Dreissena will not always have large effects on the standing stocks of spent shells in freshwater ecosystems. If dense populations of unionids are simply displaced by Corbicula or Dreissena, the high shell production rates of the alien bivalves may compensate for their relatively high decay rates and have little net effect on the standing stock of spent shell material. However, if the aliens move into sites where native bivalves are scarce or absent, habitat engineering by the aliens may fundamentally alter habitat structure and material cycling by increasing standing stocks of spent shells. Of course, even if standing stocks of spent shells are unchanged, the quality (size, surface area for biogeochemical reactions, mobility, resistance to crushing) of spent shells and shell fragments of the alien may differ markedly from that of the native unionids, especially in the case of Dreissena. Little is known about the ecological significance of such qualitative changes, which may be important in determining the nature of freshwater benthic habitats.

\section{Acknowledgments}

We thank Jim Layzer for providing Corbicula shells, Jon Cole for helpful discussions, Caryn Vaughn, Roger Jones and anonymous reviewers for helpful comments, the IES analytical lab for Ca analyses, the Mohonk Preserve and The Nature Conservancy for providing access to study sites, and the A.W. Mellon Foundation for funding. This is a contribution to the program of the Institute of Ecosystem Studies.

\section{References}

Aldridge D.W. \& McMahon R.F. (1978) Growth, fecundity, and bioenergetics in a natural population of the Asiatic freshwater clam, Corbicula manilensis Philippi, 
from north central Texas. Journal of Molluscan Studies, 44, 49-70.

Barbiero R.P., Tuchman M.L. \& Millard E.S. (2006) Postdreissenid increases in transparency during summer stratification in the offshore waters of Lake Ontario: is a reduction in whiting events the cause? Journal of Great Lakes Research, 32, 131-141.

Butler J.N. (1991) Carbon Dioxide Equilibria and their Applications. CRC Press, Chelsea, MI, U.S.A.

Chase M.E. \& Bailey R.C. (1996) Recruitment of Dreissena polymorpha: does the presence and density of conspecifics determine the recruitment density and pattern in a population? Malacologia, 38, 19-31.

Chase M.E. \& Bailey R.C. (1999) The ecology of the zebra mussel (Dreissena polymorpha) in the lower Great Lakes of North America: II. Total production, energy allocation, and reproductive effort. Journal of Great Lakes Research, 25, 122-134.

Chauvaud L., Thompson J.K., Cloern J.E. \& Thouzeau G. (2003) Clams as $\mathrm{CO}_{2}$ generators: the Potamocorbula example in San Francisco Bay. Limnology and Oceanography, 48, 2086-2092.

Cleven E.-J. \& Frenzel P. (1993) Population dynamics and production of Dreissena polymorpha (Pallas) in River Seerhein, the outlet of Lake Constance (Obersee). Archiv für Hydrobiologie, 127, 395-407.

Compere E.L. \& Bates J.M. (1973) Determination of calcite: aragonite ratios in mollusc shells by infrared spectra. Limnology and Oceanography, 18, 326-331.

Dame R.F. (1996) Ecology of Marine Bivalves: An Ecosystem Approach. CRC Press, Boca Raton.

Fritz L.W., Ragone L.M., Lutz R.A. \& Swapp S. (1990) Biomineralization of barite in the shell of the freshwater Asiatic Clam Corbicula fluminea (Mollusca: Bivalvia). Limnology and Oceanography, 35, 756-762.

Glover C.P. \& Kidwell S.M. (1993) Influence of organic matrix on the post-mortem destruction of molluscan shells. Journal of Geology, 101, 729-747.

Green R.H. (1980) Role of a unionid clam population in the calcium budget of a small Arctic lake. Canadian Journal of Fisheries and Aquatic Sciences, 37, 219-224.

Gutierrez J.L., Jones C.G., Strayer D.L. \& Iribarne O.O. (2003) Mollusks as ecosystem engineers: their functional roles as shell producers in aquatic habitats. Oikos, 101, 79-90.

Harper E.M. (2000) Are calcitic layers an effective adaptation against shell dissolution in the Bivalvia? Journal of Zoology, 251, 179-186.

Karatayev A.Y., Burlakova L.E. \& Padilla D.K. (2005) Contrasting distribution and impacts of two freshwater exotic suspension feeders, Dreissena polymorpha and Corbicula fluminea. In: The Comparative Roles of Suspension-feeders in Ecosystems (Eds R.F. Dame \& S. Olenin), pp. 239-262. Springer, Dordrecht.

Kat P.W. (1985) Convergence in bivalve conchiolin layer microstructure. Malacological Review, 18, 97-106.

Nalepa T.F. \& Gauvin J.M. (1988) Distribution, abundance, and biomass of freshwater mussels (Bivalvia: Unionidae) in Lake St. Clair. Journal of Great Lakes Research, 14, 411-419.

Pathy D.A. \& Mackie G.L. (1993) Comparative shell morphology of Dreissena polymorpha, Mytilopsis leucophaeta, and the "quagga" mussel in North America. Canadian Journal of Zoology, 71, 1012-1023.

Powell E.N., Kraeuter J.N. \& Ashton-Alcox K.A. (2006) How long does an oyster reef last? Estuarine, Coastal and Shelf Science, 69, 531-542.

Stainton M.P. (1974) A syringe gas-stripping procedure for gas-chromatographic determination of dissolved inorganic and organic carbon in freshwater and carbonates in sediments. Journal of the Fisheries Research Board of Canada, 30, 1441-1445.

Strayer D.L., Cole J.J., Likens G.E. \& Buso D.C. (1981) Biomass and annual production of the freshwater mussel Elliptio complanata in an oligotrophic softwater lake. Freshwater Biology, 11, 435-440.

Strayer D.L., Hunter D.C., Smith L.C. \& Borg C. (1994) Distribution, abundance, and role of freshwater clams (Bivalvia: Unionidae) in the freshwater tidal Hudson River. Freshwater Biology, 31, 239-248.

Strayer D.L., Caraco N.F., Cole J.J., Findlay S. \& Pace M.L. (1999) Transformation of freshwater ecosystems by bivalves: a case study of zebra mussels in the Hudson River. BioScience, 49, 19-27.

Vaughn C.C. \& Hakenkamp C.C. (2001) The functional role of burrowing bivalves in freshwater ecosystems. Freshwater Biology, 46, 1431-1446.

Vincent B. \& Lafontaine N. (1984) Cycle de développement, croissance et production de Sphaerium striatinum (Bivalvia: Pisidiidae) dans le Saint-Laurent (Québec). Canadian Journal of Zoology, 62, 2418-2424.

Vincent B., Vaillancourt G. \& Lafontaine N. (1981) Cycle de développement, croissance et production de Pisidium amnicum (Mollusca: Bivalvia) dans le SaintLaurent (Québec). Canadian Journal of Zoology, 62, 2418-2424.

Walz N. (1979) The energy balance of the freshwater mussel Dreissena polymorpha Pallas in laboratory experiments and in Lake Constance. V. Seasonal and nutritional changes in the biochemical composition. Archiv für Hydrobiologie Supplementband, 55, 235-254.

(Manuscript accepted 5 April 2007) 